\title{
Zinc and copper content in soil and plant during different vegetation periods
}

\author{
(C) Olga Yu. Shiryaeva \\ Department of Chemistry and Methods of Teaching Chemistry. Orenburg State Pedagogical University. \\ Sovetskaya St., 19. Orenburg, 460014. Russia.Phone: +7 (3532) 77-24-52. E-mail: schirjaewa@yandex.ru
}

Keywords: copper, zinc, eustoma, biological absorption coefficient, «Greenhouse «Iceberg».

\begin{abstract}
Important biogenic elements of plants are zinc and copper, which come into them from the soil in the form of cations. Plants selectively absorb the elements they need in accordance with physiological and biochemical needs, as well as the characteristics of their vegetation. Copper and zinc are part of the enzymes that are necessary for the normal course of many biochemical reactions. Lack or excess of any chemical element causes a violation of the normal course of biochemical and physiological processes in plants. The paper presents the results of the study of zinc and copper content in the soil, as well as in the above-ground and underground organs of the studied plant object. Quantitative determination of zinc and copper was carried out on an atomic absorption spectrometer. As an object of study, a flower plant of the Gentian family (lat. Gentianáceae), genus Eustoma (lat. Eustoma), grade Aube Pink Picotee. Vegetation experiments were carried out on the basis of LLC "Greenhouse "Iceberg". According to the data, the content of zinc and copper in the organs of the studied plant decreases in a number of root - aboveground part - flower. In different periods of vegetation there is a different accumulation of copper and zinc in the aboveground and underground organs. The root of this plant performs a barrier function, blocking the flow of copper into the plant from the soil at 27 weeks of development. In this case, the zinc content in the root of the plant during this period increases significantly, but this figure in the above-ground part of the plant varies slightly. According to the calculated average value of the biological absorption coefficient, it can be seen that the accumulation of zinc in the plant occurs to a greater extent than the accumulation of copper.
\end{abstract}

\section{References}

[1] V.N. Bashkin. Biogeochemistry. Studies' benefit. Moscow: Higher. SHK. 2008. 423p. (russian)

[2] The content of copper and zinc in the system of "soil-plant" in the geochemical province of the southern Urals. Proceedings of the Samara scientific center of the Russian Academy of Sciences. 2011. Vol.13. No.1. P.31-35. (russian)

[3] L.V. Galaktionova, M.A. Stepanova, A.V. Teslya, A.A. Anufrienko. Comparative analysis of the ability of representatives of the flora of urbanized areas to accumulate heavy metals. Vestnik OGU. 2013. No.10(159). P.186-188. (russian)

[4] GOST R 53380-2009 Soils and soils. The soil of the greenhouse. Technical conditions. Moscow: STANDARTINFORM. 2009. (russian)

[5] N.F. Gusev, A.V. Filippova, V.V. Trubnikov, O.N. Americhina. The content of heavy metals in raw materials yarrow in the zone of influence of the Gaysky mining and processing plant. News of Orenburg state agrarian University. 2015. No.6(56). P.218-220. (russian)

[6] V.V. Dobrovolsky. Fundamentals of biogeochemistry: Textbook for students. higher. studies, institutions. Moscow: Publishing center "Academy". 2003. 400p. (russian)

[7] A.A. Drogaytseva, G.V. Petrov. Accumulation of heavy metals in the ecosystem "soil-plant" Melampyrum, arvense of the Orenburg region steppe zone. News of Orenburg state agrarian University. 2014. No.6(50). P.144-146. (russian)

[8] V.A. Litvinskiy, E.A. Grishina, V.V. Nosikov, and S.L. Belopukhov. Application of ICP-AES technique for determination of zinc in plants and plant products. Butlerov Communications. 2018. Vol.54. No.4. P.140148. DOI: $10.37952 /$ ROI-jbc-01/18-54-4-140

[9] S.S. Medvedev. Plant Physiology: textbook. St.Petersburg: Bkhv-Petersburg. 2012. 227p. (russian)

[10] A.F. Titov, V.V. Talanova, N.M. Kaznina. Physiological basis of plant resistance to heavy metals: a tutorial. Institute of biology, Karelian research centre RAS. Petrozavodsk: Karelian research centre of Russian Academy of Sciences. 2011. 77p. (russian) 